\title{
TINJAUAN YURIDIS TERHADAP SURAT KUASA MEMBEBANKAN HAK TANGGUNGAN (SKMHT) SEBAGAI MEDIA PENGIKATAN JAMINAN PADA PROSES KREDIT TAKE OVER PADA PERUSAHAN PERBANKAN
}

\author{
Oleh \\ Dhevi Nayasari Sastradinata \\ Dosen Fakultas Hukum Universitas Islam Lamongan
}

\begin{abstract}
ABSTRAK
agunan yang lazim dan banyak dijadikan jaminan dalam usaha kredit perbankan adalah tanah dan atau bangunan, sehingga dalam pengikatan jaminan atas kredit yang telah diberikan berupa pembebanan Hak Tanggungan atas tanah yang menjadi agunan tersebut.Perkembangan dunia sangat kompetitif, hal itu yang menjadikan adanya perebutan calon nasabah (debitur), penyebabnya adalah perkembangan target market,maka tidak bisa terhindarkan adanya proses saling take over nasabah dari bank satu ke bank lainnya.Untuk mengetahui lamanya jangka waktu berlakunya Surat Kuasa Membebankan Hak Tanggungan (SKMHT) pada pengikatan atas pengikatan dan pembebanan jaminan dan mengenai akibat hukum atas terbitnya Surat Kuasa Membebankan Hak Tanggungan (SKMHT).dengan tujuan untuk meghasilkan bahan pustaka dan gambaran mengenai jangka waktu berlakunya SKMHT dan Akibat Hukum terbitnya Surat Kuasa Membebankan Hak Tanggungan (SKMHT) pada proses Take Over.Dengan menggunakan type penelitian hukum normatif dan penelitian hukum sosiologis atau empiris.
\end{abstract}

Kata Kunci : Tinjauan yuridis, Surat Kuasa ,Membebankan Hak Tanggungan, kredit take over.

\section{PENDAHULUAN}

\section{Latar Belakang Masalah}

perkembangan dunia perbankan terutama pada aspek pemberian kredit di segment small and micro banking sangat kompetitif.Saat ini semua berlomba melayani kredit pada segment small and micro, karena dianggap bahwa segment small and micro banking sangat profitable, sehingga hal itu yang menjadikan adanya perebutan calon nasabah (debitur) baik yang belum pernah menjadi nasabah suatu bank, maupun calon debitur yang saat ini masih menjadi nasbah di bank lain, penyebabnya adalah perkembangan target market yang relative stagnant, disisi lain perkembangan lembaga keuangan baik perbankan maupun non perbankan sangat cepat, maka tidak bisa terhindarkan adanya proses saling take over nasabah dari bank satu ke bank lainnya
Oleh karenanya pada beberapa lembaga perbankan yang bergerak di segment micro saat ini banyak yang membuat aturan internal dan kebijakan kredit yang intinya mencegah nasabah yang mempunyai historical loan yang baik untuk keluar/ melunasi fasilitas pinjamannya, sehingga hal itu pula yang tidak jarang menjadi hambatan pada proses kredit take over pada suatu bank, terutama untuk fasilitas kredit secure loan (fasilitas kredit dengan pinjaman), dimana seseorang yang saat ini menjadi nasabah kredit secure loan dari bank A, ia ingin pindah menjadi nasabah kredit secure loan pada bank B dengan cara bank B melunasi fasilitas kreditnya yang ada di bank A, karena bank B akan mengambil alih jaminan yang ada di bank $A$, artinya pada saat bank B mencairkan fasilitas kredit dengan cara melunasi kredit yang ada di 
bankA, agunan yang akan dijaminkan masih berada dan masih dalam ikatan pembebanan di bank A, sedangkan bank B telah melakukan pengikatan jaminan yang sama melalui Surat Kuasa Membebankan Hak Tanggungan.

\section{METODE PENELITIAN Tipe Penelitian}

Tipe penelitian yang digunakan dalam penelitian ini adalah penelitian hukum normatif. Penelitian normatif digunakan untuk menemukan hukum bagi suatu perkara in concreto yaitu suatu usaha untuk menemukan apakah hukumnya sesuai untuk diterapkan dan digunakan untuk menyelesaikan suatu perkara. Oleh karena itu tipe penelitian yang dilakukan dalam penelitian ini adalah dilakukan secara normatif mengenai Akibat Hukum yang timbul dengan penerbitan Surat Kuasa Membebankan Hak Tanggungan yang tidak dan atau menjadi Akta Pemberian Hak Tanggungan.

\section{Pendekatan Masalah}

pendekatan yang digunakan adalah pendekatan perundang-undangan (statue approach) dalam pendekatan perundangundangan peneliti perlu memahami hierarki, dan asas-asas dalam perundangundangan. Selain itu juga digunakan pendekatan konsep (conseptual). Pendekatan konsep ini di gunakan dalam rangka untuk melihat konsep-konsep Akibat Hukum yang timbul dengan penerbitan Surat Kuasa Membebankan Hak Tanggungan yang tidak dan atau menjadi Akta Pemberian Hak Tanggungan.Dari pengertian tersebut, secara singkat dapat dikatakan bahwa yang dimaksud sebagai statue berupa legislaasi dan regulasi. Jika demikian, pendekatan perundang-undangan adalah pendekatan dengan menggunakan legislasi dan regulasi.

\section{Bahan Hukum}

Dalam penelitian ini digunakan data sekunder sebagai penyalur kelengkapan data. Data sekunder merupakan metode pengumpulan data yang dilakukan secara tidak langsung dengan penelitian kepustakaan, guna mendapatkan landasan teoritis dan beberapa pendapat maupun tulisan para ahli dan juga untuk memperoleh informasi baik dalam bentuk ketentuan formal maupun data melalui naskah resmi yang ada. Data sekunder dalam penelitian ini dikelompokkan menjadi 2 (dua), yaitu :

a. Bahan Hukum Primer, yaitu bahan yang mengikat, terdiri dari :

1. Undang-undang Nomor 4 tahun 1996, tentang Hak Tanggungan

2. Undang-undang UUPA nomor 5 tahun 1960

3. Kitab Undang-undang Hukum Perdata

4. Undang-undang nomor 10 tahun 1998 tentang perbankan

b. Bahan Hukum Sekunder, yaittu bahan yang memberi penjelasan bagi bahan primer, terdiri dari :

1. Buku-buku atau hasil penelitian yang membahas tentang Surat Kuasa Membebankan Hak Tanggungan.

2. Majalah-majalah atau dokumen-dokumen yang berkaitan dengan pengikatan Pengikatan Hak Tanggungan.

\section{Prosedur Pengumpulan Bahan Hukum}

Baik bahan hukum primer maupun sekunder dikumpulkan berdasarkan topik permasalahan yang dirumuskan dan di klarifikasi menurut sumber untuk dikaji secara komprehensif.

\section{Pengolahan dan Analisis Bahan Hukum} Adapun bahan hukum yang diperoleh dalam penelitian adalah studi kepustakaan aturan perundang undangan yang penulis uraikan dan dihubungkan sedemikian rupa sehingga disajikan dalam penulisan yang lebih sistematis guna menjawab perumusan masalah yang dirumuskan dan dilakukan secara deduktif yakni menarik kesimpulan dari suatu permasalahan yang bersifat umum terhadap permasalahan kongkrit yang dihadapi. 
HASIL PENELITIAN DAN

PEMBAHASAN

\section{Jangka waktu pembuatan Surat Kuasa Membebankan Hak Tanggungan}

Surat Kuasa Membebankan Hak Tanggungan tidak diperlukan, selama pemberi kuasa bisa hadir dan menandatangani Akta Pemberian Hak Tanggungan atas jaminan yang diagunkan kepada pihak kreditur di hadapan Notaris/ PPAT, namun ketika proses kredit Take Over, maka pengikatan jaminan atas fasilitas kredit, memakai media Surat Kuasa Membebankan Hak Tanggungan, karena pada saat penandatanganan Perjanjian Kredit, jaminan tidak bisa langsung diikat dengan Akta Pemberian Hak Tanggungan, sehingga pemberi kuasa tidak bisa hadir dan menandatangani Akta Pemberian Hak Tanggungan sendiri dihadapan notaris, karena pada saat penandatanganan Perjanjian Kredit posisi jaminan masih berada di Bank atau Lembaga Keuangan lain, atau Surat Kuasa Membebankan Hak Tanggungan ada dikarenakan fasilitas pinjaman pada plafon tertentu dimana menurut aturan internal Bank pengikatan jaminan tidak perlu dibebankan Hak Tanggungan, sehingga sebagai media pengikatan jaminannya di lakukan melalui Surat Kuasa Membebankan Hak Tanggungan, hal itu didasarkan atas pasal 15 ayat (5) Undangundang Hak Tanggungan yang menyatakan:

"Ketentuan sebagaimana dimaksud pada ayat (3) dan ayat (4) tidak ber-laku dalam hal Surat Kuasa Membebankan Hak Tanggungan diberikan untuk menjamin kredit tertentu yang ditetapkan dalam peraturan perundang-undangan yang berlaku."

Dimana menurut pasal 15 ayat (5) tersebut diatas, bahwa berlakunya Surat Kuasa Membebankan Hak Tanggungan adalah menyesuaikan jangka waktu (tenor) kredit yang diberikan kreditur (Bank) kepada debitur. Sehingga masa Surat Kuasa Membebankan Hak Tanggungan akan berakhir seiring dengan jangka waktu kredit berakhir.

Selain itu, masa berlakunya Surat Kuasa Membebankan Hak Tanggungan (SKMHT), akan berlaku selama 1 (satu) bulan dan 3 (tiga) bulan sejak ditandatanganinya Surat Kuasa Membebankan Hak Tanggungan, hal itu seperti yang diatur dalam pasal 15 Undang-undang Hak Tanggungan, khususnya pada ayat (3) dan ayat (4), yang berbunyi:

Pasal 15 ayat (3): Surat Kuasa Membebankan Hak Tanggungan mengenai hak atas tanah yang sudah terdaftar wajib diikuti dengan pembuatan Akta Pemberian Hak Tanggungan selambat-lambatnya 1 (satu) bulan sesudah diberikan.

Pasal 15 ayat (4): Surat Kuasa Membebankan Hak Tanggungan mengenai hak atas tanah yang belum terdaftar wajib diikuti dengan pembuatan Akta Pemberian Hak Tanggungan selambat-lambatnya 3 (tiga) bulan sesudah diberikan.

\section{Akibat Hukum atas Penerbitan Surat Kuasa Membebankan Hak Tanggungan (SKMHT) yang tidak dilanjutkan menjadi Akta Pemberian Hak Tanggungan (APHT)}

Surat Kuasa Membebankan Hak Tanggungan Dalam pasal 15 ayat 2 Undang-undang No.4 Tahun 1996 tentang Hak Tanggungan atas tanah berikut bendabenda yang berkaitan dengan tanah menyebutan bahwa "Kuasa untuk membebankan hak tanggungan tidak dapat ditarik kembali atau tidak dapat berakhir oleh sebab apapun juga kecuali karena kuasa tersebut telah dilaksanakan atau karena telah habis jangka waktunya sebgaimana dimaksus ayat (3) dan ayat (4)" dan Pada ayat 6 Pasal 15 Undangundang ini menjelaskan bahwa "Surat Kuasa Membebankan Hak Tanggungan yang tidak diikuti dengan pembuatan Akta 
Pemberian Hak Tanggungan dalam waktu yang ditentukan sebagaimana dimaksud dalam ayat (3) atau ayat (4) atau waktu yang ditentukan menurut ketentuan seabagaimana yang dimaksud pada ayat (5) batal demi hukum".

Akibat Hukum atas Penerbitan Surat
Kuasa Membebankan Hak Tanggungan
(SKMHT) yang dilanjutkan menjadi Akta Pemberian Hak Tanggungan (APHT)

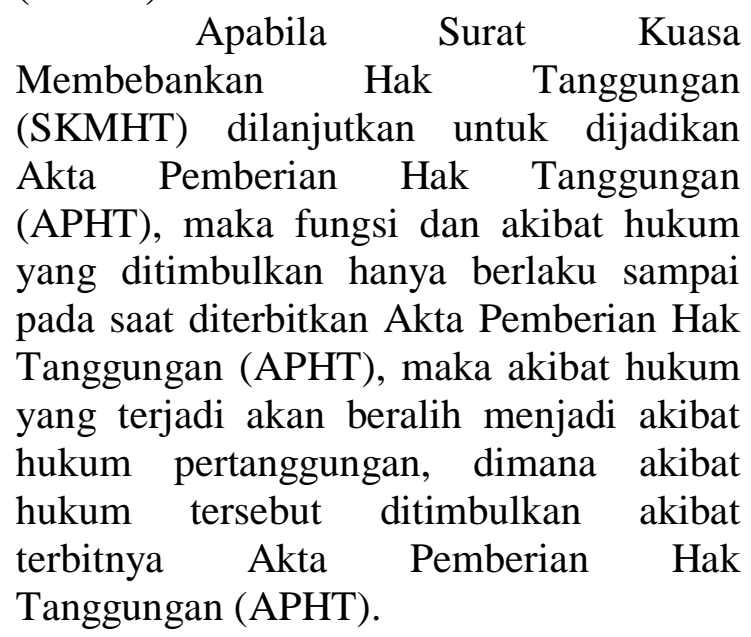

Akibat hukum yang terjadi karena pengikatan jaminan dengan Akta Pemberian Hak Tanggungan (APHT) adalah antara lain seperti yang dinyatakan dalam Undang-undang nomor 4 tahun 1996 tentang Hak Tanggungan

\section{KESIMPULAN DAN SARAN Kesimpulan}

Jangka waktu 1 (satu) bulan, SKMHT ini untuk jaminan yang telah terdaftar, SKMHT ini diperlukan karena pada saat pemberian kredit jaminan dalam proses balik nama atau jaminan masih berada di bank lain karena pemberian kredit dengan proses Take Over.Jangka Waktu 3 (tiga) bulan, SKMHT ini untuk jaminan yang belum terdaftar (proses sertifikat).Jangka waktu sesuai tenor kredit yang diberikan oleh bank. SKMHT ini berlaku bagi plafon kredit tertentu menurut aturan internal bank.

Mengenai akibat hukum atas terbitnya Surat Kuasa Membebankan Hak Tanggungan (SKMHT) tidak lepas dari jenis jangka waktu berlakunya SKMHT, karena jika SKMHT akan menjadi Akta Pemberian Hak Tanggungan (APHT) maka akibat hukum adalah sifat dan ketentuan yang melekat pada APHT termasuk sifat eksekutorial. Apabila SKMHT berlaku untuk jangka waktu kredit, maka akibat hukum yang terjadi adalah seperti Surat Kuasa lain yaitu beralihnya segala hal yang dikuasakan ke penerima kuasa, termasuk apabila dikemudian ditingkatkan menjadi Akta Pemberian Hak Tanggungan (APHT).

\section{Saran}

Setelah menganalisa data-data yang ada, maka saran penulis mengenai Tinjauan yuridis terhadap Surat Kuasa Membebankan Hak Tanggungan (SKMHT) sebagai media pengikatan jaminan pada proses kredit take over pada perusahaan perbankan, saran untuk perbankan sendiri agar memastikan kelengakapan dan keabsahan dokument kredit, mulai dari identitas dari calon debitor, dokumen keuangan dan dokumen legalitas lainnya, terutama mengenai dokumen jaminan, karena pada saat proses pemberian kredit dokumen asli jaminan masih berada di bank lain (jika proses Take Over). Dan perbankan lebih teliti dalam membuat analisa kebutuhan keuangan calon debitur, tujuan pengajuan kredit, kelayakan calon debitur, mulai dari usaha, kemampuan dan jaminan.Serta untuk Debitor atau Masyarakat Bagi calon debitor dan masyarakat agar lebih mempelajari dan mendalami tentang proses kredit dan pengikatan jaminan dengan benar, sehingga tidak terjadi salah pengertian dan salah pemahaman, terutama tentang akibat pengikatan jaminan.

\section{DAFTAR PUSTAKA}

\section{Literatur}

a. Soerjono Soekanto. pengantar penelitian hukum. penerbit Universitas Indonesia (UIPress).Jakarta. 1986.

b. Peter Mahmud Marzuki. Penelitian $\underline{\text { Hukum. Penerbit Kencana Prenada }}$ Media Group. 
Jakarta.2010.

c. Soerjono Soekanto. Pengantar Penelitian Hukum. penerbit Universitas Indonesia (UI-Press). 1986.

d. KAMSIR, Bank dan Lembaga Keuangan lainnya, Edisi Revisi 2014, Jakarta 17 Juni

2014.

e. KAMSIR, Dasar-dasar Perbankan, Raja Grafindo Persada, Jakarta 2002.

\section{Peraturan Perundang-undangan}

a. Kitab Undang-undang Hukum Perdata

b. Undang-undang nomor 4 tahun 1996 tentang Hak Tanggungan

c. Undang-undang nomor 10 Tahun 1998 tentang Perbankan

\section{Artikel}

a. raypratama.blogspot.com/2012/02/pe ngertian-surat-kuasa-membebankanhak.html

b. http://pobox2000.blogspot.co.id/2010/11/suratkuasa.html

c. https://operasionalperbankan.wordpres s.com/2012/07/10/masaberlakuskmht/ga daibpkbmobil.co.id/pengertian-dandefinisi-take-over-kredit/ 